\title{
PHOTO REALISTIC 3D MODELING WITH UAV: GEDİK AHMET PASHA MOSQUE IN AFYONKARAHISAR
}

\author{
M.Uysal ${ }^{\text {a }}$, A.S.Toprak ${ }^{\text {b }}$, N.Polat ${ }^{\text {a }}$ \\ a Afyon Kocatepe Üniversitesi, Mühendislik Fakültesi, Harita Mühendisliği Bölümü - \\ (muysal,npolat@aku.edu.tr) \\ b Afyon Kocatepe Üniversitesi, Uzaktan Eğitim Meslek Yüksek Okulu, - (astoprak@aku.edu.tr)
}

KEY WORDS: Cultural Heritage, Photogrammetry, 3D modelling, UAV

\begin{abstract}
:
Many of the cultural heritages in the world have been totally or partly destroyed by natural events and human activities such as earthquake, flood and fire until the present day. Cultural heritages are legacy for us as well; it is also a fiduciary for next generation. To deliver this fiduciary to the future generations, cultural heritages have to be protected and registered. There are different methods for applying this registry but Photogrammetry is the most accurate and rapid method. Photogrammetry enables us to registry cultural heritages and generating 3D photo-realistic models. Nowadays, 3D models are being used in various fields such as education and tourism. In registration of complex and high construction by Photogrammetry, there are some problems in data acquisition and processing. Especially for high construction's photographs, some additional equipment is required such as balloon and lifter. In recent years The Unmanned Aerial Vehicles (UAV) are commonly started to be used in different fields for different goals. In Photogrammetry, The UAVs are being used for particularly data acquisition. It is not always easy to capture data due to the situation of historical places and their neighbourhood. The use of UAVs for documentation of cultural heritage will make an important contribution.
\end{abstract}

The main goals of this study are to survey cultural heritages by Photogrammetry and to investigate the potential of UAVs in 3D modelling. In this purpose we surveyed Gedik Ahmet Pasha Mosque photogrammetricly by UAV and will produce photorealistic 3D model. Gedik Ahmet Pasha, The Grand Vizier of Fatih Sultan Mehmet, has been in Afyonkarahisar during the campaign to Karaman between the years of 1472-1473. He wanted Architect Ayaz Agha to build a complex of Bathhouse, Mosque and a Madrasah here, Afyon, due to admiration of this city. Gedik Ahmet Pasha Mosque is in the centre of this complex. Gedik Ahmet Pasha Mosque is popularly known as Imaret Mosque among the people of Afyon. Gedik Ahmet Pasha Complex is a foundation. For this reason all its expenses are recorded. Furthermore renovations of all buildings in this complex are placed on them with a inscription. According to records and inscriptions The Imaret Mosque has been restored several times. The two significant of these restorations were made after the earthquakes in 1668 and 1792. Lastly, after the renewing lead plating of domes in 1969, the Mosque has gotten its current final situation. The dimensions of Mosque are $29.20 \times 35.40$ in meter and it has built by a plan of inverse capital (T). There are two domes covering the main worship and it is one of the most important examples of Ottoman architecture with three of dome both side in direction of east to west. At the north side of the Mosque, there is a place for last congregations with five domes. Minaret is at the north-east side of the mosque. It has got one balcony (surrounding the minaret) and has been structured by cut stone with a shape of fluting. It has been covered by dark blue tile between these flutings. The main gate of mosque is made of pen inlaid marble.

It is aimed to survey Gedik Ahmet Pasha Mosque photogrammetricly and to model it in 3D photo-realistic. In this study, South NTS-352 Total Station is used to constitute a closed polygon with 8 point. We used 350 ground control point in the field study. It is made levelling to measure elevation of polygon points. For photographs, we used Canon A 180 camera and UAV. Photomodeler software is used to process both camera's and UAV's photographs independently. The facades of mosque are derived and all 3D models of Mosque were merged. This merged model is covered with high resolution photographs for obtaining 3D photo-realistic models of Gedik Ahmet Pasha Mosque.

\section{INTRODUCTION:}

Historical artifacts are cultural legacies that hosting Many hundreds years of knowledge. This knowledge has to be transferred to the next generations. These historical heritages reflect the life style and aesthetic understanding of elder civilization as well as being cultural assets that hosting all changes in time such as wars and earthquakes. The documentation and conservation of the natural tissues of historical monument without damaging is indispensable element for transferring future generations. It is a fact that cultural heritages not only in our country (Turkey) but also in many part of the world were damaged and being damaged. Because of this reason cultural heritages are partly documented in time all over the world.

The work of documentation of historical places and cultural heritages is complex and multi-faceted process (Kulur, 2005). Documentation of historical or cultural structure covers the entire steps which is necessary for determining current state of the structure (shape and position) in three-dimensional space that are surveys, process, storage and presentation (Georgopoulos and Ioannidis, 2004). There are a few techniques for documentation of cultural heritages (Bohler and Heinz, 
1999). These techniques which are very important and necessary, are traditional surveys, topographic techniques, photogrammetric surveys and scanning technique (Bohler and Heinz, 1999, Scherer, 2002).

Nowadays, reconstruction of building in 3D model is very popular due to the developments in digital photogrammetry parallel to computer technology (Yakar et al., 2011). Today 3D building models become almost indispensable for city planning and tourism (Suveg and Vosselman, 2000). At this point, it is a huge advantage that photogrammetry can provide reliable information in a short time (M. Yakar and H.M. Y1lmaz, 2008). But for high buildings, sometimes it is difficult to get proper photographs. The Unmanned Arial Vehicles are solving this problems.

UAVs are to be understood as uninhabited and reusable motorized aerial vehicles which are remotely controlled, semi-autonomous or have a combination of these capabilities, and that can carry various types of payloads, making them capable of performing specific tasks within the earth's atmosphere, or beyond, for a duration, which is related to their missions (Blyenburgh P.1999) The term UAV is used commonly in the computer science and artificial intelligence community, but terms like Remotely Piloted Vehicle (RPV), Remotely Operated Aircraft (ROA), Remote Controlled (RC) Helicopter, Unmanned Vehicle Systems (UVS) and Model Helicopter are often used. The RC- and model helicopters are clearly defined by the Unmanned Vehicle Systems International Assosciation as mini, close short and medium range UAVs depending on their size, endurance, range and flying altitude (Eisenbeiss, 2004, Remondino 2011b). The UAVs system was firstly applied for military goals and in time the usage of UAVs in civilian applications is increasing. In 1979 Przybilla and Wester-Ebbinghaus applied one of the earliest experiments with fixed wing UAVs for geomatics applications.

Documantation of cultural heritages requires speed and reliable data. Photogrammetry mostly full fills these needs. But the environments conditions and the size of the objects can prevent the data acquisition with classic photogrammetric methods. Today UAVs are using for photogrammetric data collections widespreadly. UAV Photogrammetry is a new terminology and describes photogrammetric measurement platforms, which operate as either remotely controlled, semi-autonomously, or autonomously, all without a pilot sitting in the platform, and the photogrammetric processing of UAV images (Eisenbeiss, 2009).

UAVs are establishing as serious alternative for traditional photogrammetric data capture, especially while aiming at mapping application with high spatial and temporal resolution. UAV-based photogrammetric data collection just requires small, light UAV platform with a control system and standard consumer grade digital camera (Haala N., et. Al, 2011)

In this study, it is aimed to reconstruction the Gedik Ahmet Pasha Mosque that is in the city of Afyonkarahisar, in 3D model by the techniques of photogrammetry. Gedik Ahmet Pasha was The Grand Vizier of Fatih Sultan Mehmet. He made Architect Ayaz Agha to build a complex of Bathhouse, Mosque and a Madrasah here, Afyonkarahisar, due to admiration of this city. Gedik Ahmet Pasha Mosque is in the centre of this complex (Fig. 1).

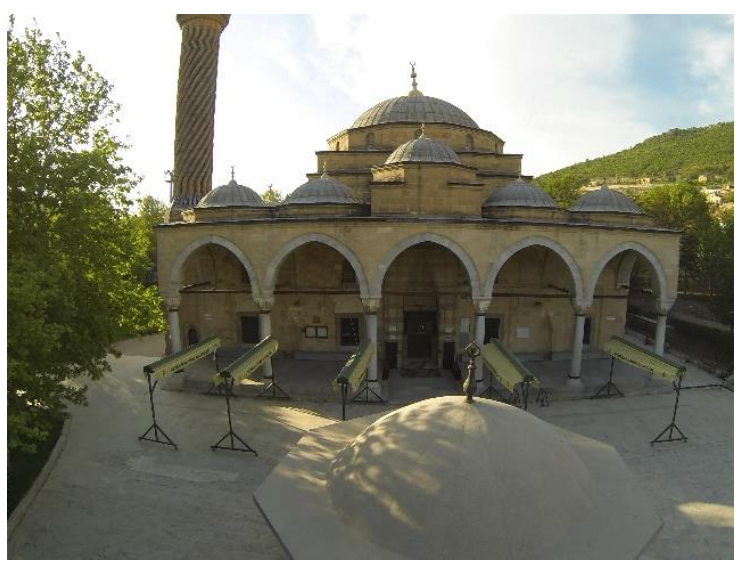

Figure 1. Gedik Ahmet Pasha Mosque

\section{DATA ACQUISITION}

For data acquisition, the control points are surveyed in local system and photographs are taken. The mosque is covered with 6 points on the polygon. Not only Angles and distances are surveyed but also levels are determined with levelling. For the detail points of the Mosque, the façade photographs of the mosque are used. In the selection of detail points, the physical properties of the surface and sharp lines are considered. Same detail point on the mosque surface is surveyed from different polygon points as a control survey. In this study 350 ground control points are used.

The photogrammetric survey on the Gedik Ahmet Pasha was realized using DJI Phantom remotely piloted quadricopter (Fig. 2) that has $10 \mathrm{~m} / \mathrm{sc}$ speed on horizontal and $6 \mathrm{~m} / \mathrm{sc}$ on vertical. The UAV can stop above the any wanted point with GPS receiver in it. But all flies for data acquisition are made manually. Sometimes the GPS signal is lost due to the high trees that surround the work field so this situation affects the photographs. Battery time for a single fly depends on weight. Phantom can fly approximately 20 minutes without any weight and nearly 8 minutes with Canon A180 camera (Fig. 3) that we used. Canon A180, has $16.0 \mathrm{mp}$ resolution, is hacked and modified for taking photographs with 2 second intervals. Vibration is big problem. To reduce vibration we used sponge.

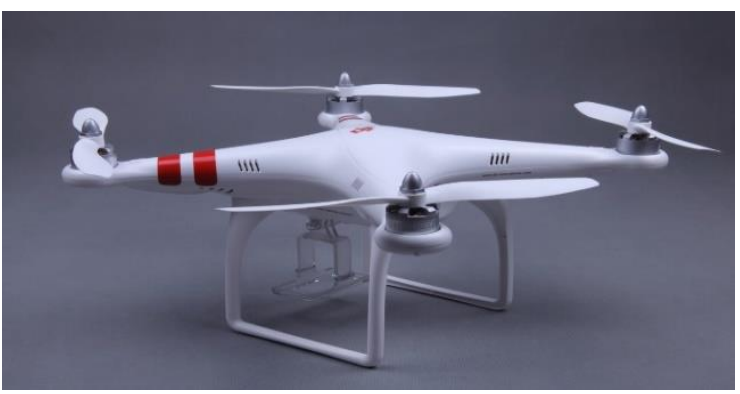

Figure 2. DJI Phantom Quadcopter 


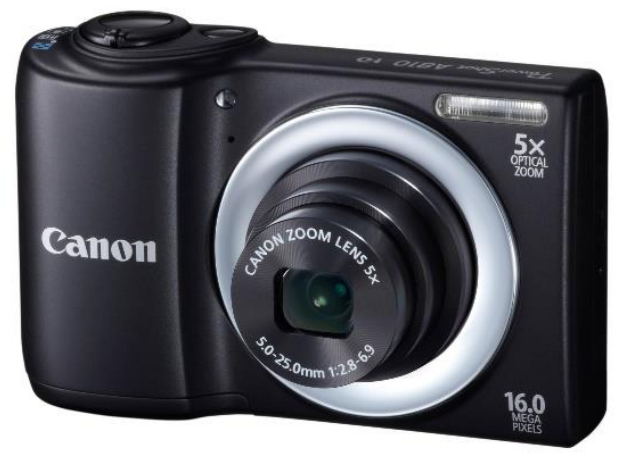

Figure 3. Canon A 180 Camera

\section{DATA PROCESSING}

Data processing consist of coordinate calculations and generating 3D model. In the field, 8 points are established as closed polygon which is covered the building. Coordinates of points are calculated in local system with surveying and levelling. Basically all surveyed detail points data in the total station is transferred to computer. In Netcad software the 3D coordinates of point are calculated. In the field work some surveys are made for controlling the detail points as same detail point is observed from different polygon points. At the result of this controls $3 \mathrm{~mm}$ differences are detected between both vertical surfaces and horizontal surfaces. At the end of all calculations and controls, the coordinates of points are saved in .txt format.

Camera calibration parameters of Canon A180 camera (Fig.4) are calculated in PhotoModeler software and saved as .cam format. For absolute orientation the txt and cam files are used. After orientation processes we are ready for drawing. All facades are drawn from photographs which have different angles for same façade (Fig.5, 6). Some details on the surface are defined from single photographs to surface. All façades are drawn stone by stone (Fig.7). At the end of the drawing, 3D model is consisted (Fig.8, 9). This model is covered with tissue automatically but some problems related covering are solved by selecting photographs manually. At the final stage, the orthophotos and facade drawns import to AutoCAD software to producing base plate.

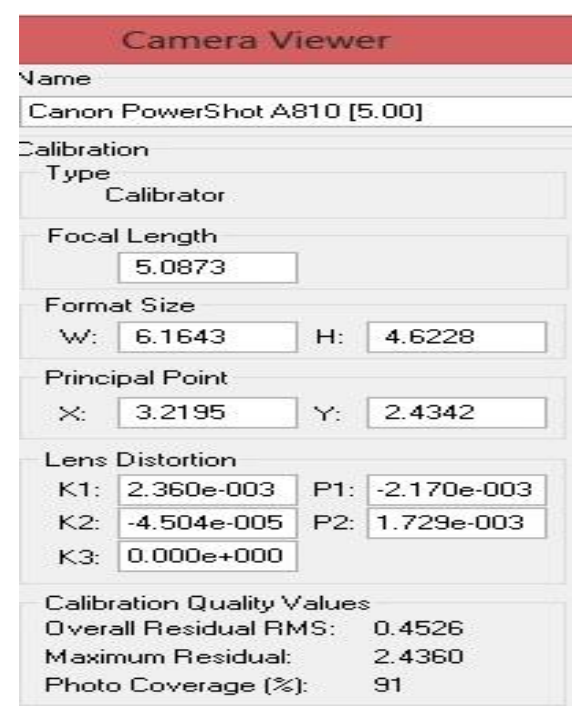

Figure 4: Camera calibration parameters

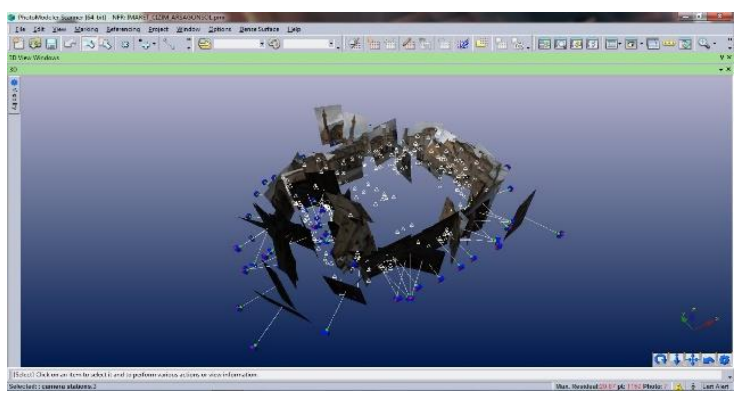

Figure 5. Camera points and control points for Mosque

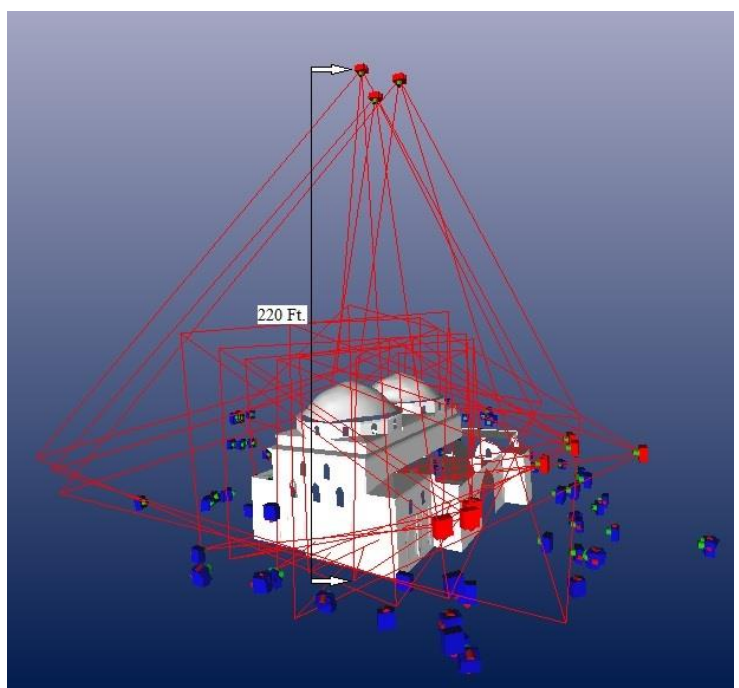

Figure 6. Photograph angles and Mosque 


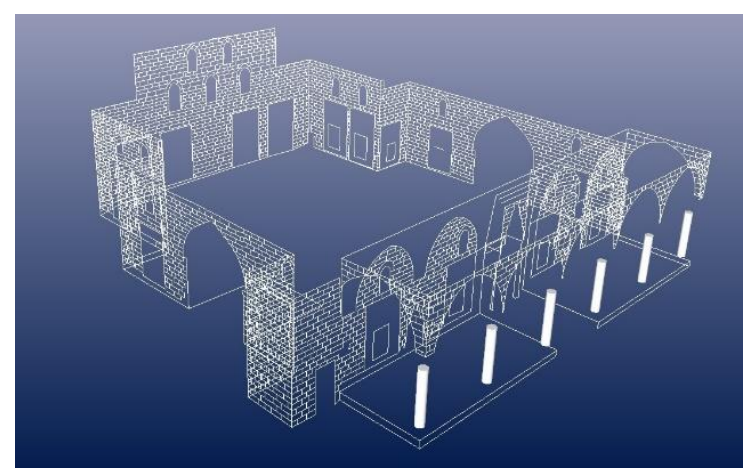

Figure 7. Drawings and Mosque's columns

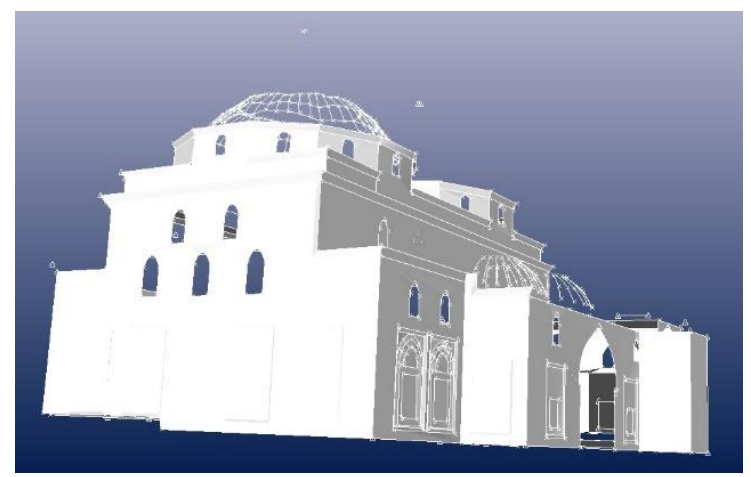

Figure 8. 3D models of Mosque'

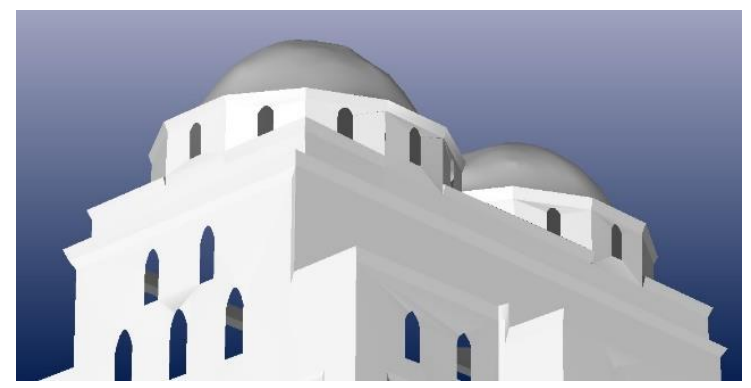

Figure 9. 3D models of Mosque'

\section{CONCLUSION}

It is important and necessary to document of cultural heritages. It seen that for protection and transferrin of the cultural heritages and historical monuments to next generation, Terrestrial Photogrammetry has been brought a breath of fresh in terms of speed and cost. When it comes to cultural sites and objects, photogrammetry provides higher 3D models (building structures) accuracy at different scales (Remondino, 2011a). It is observed that Three-dimensional models produced by using photogrammetric techniques can be used for restoration projects as base plate and also this models can export VRML format to use in different applications (Carry and Bell, 1997). In this term it is obvious that the Photogrammetry can serve different disciplines with high accuracy.

\section{REFERENCESS}

Blyenburgh, P., 1999, “UAVs - Current Situation and Considerations For The Way Forward ", Development and operation of UAVs for military and civil applications, Rhode-Saint-Genese, Belgium, 13-17 September

Carey, R., Bell, G., 1997, "The Annotated VRML 2.0 Reference Manuel”, Addison Wesley Developers Press

Eisenbeiss, H., 2009, UAV photogrammetry. Diss. ETH No. 18515, Institute of Geodesy and Photogrammetry, ETH Zurich, Switzerland, Mitteilungen Nr.105, p. 235.

Eisenbeiss, H., 2004, A mini Unmanned Aerial Vehicle (UAV): System overview and image acquisition. Proceedings of the International Workshop on Processing and Visualization using High-Resolution Imagery, November 18-20, 2004, Pitsanulok, Thailand, pp: 1-7.

Georgopoulos A., Ioannidis G., 2004, Photogrammetric and urveying methods for the geometric recording of archaeological monuments, Archaeological Surveys, FIG Working Week 2004 Athens, Greece, May 2227, 2004

Haala, N., Cramer, M., Weimer, F., Trittler, M., 2011, Performance test on UAV-based photogrammetric data collection. ISPRS ICWG I/V UAV-g conference, Zurich, Switzerland.

Kulur S, Yilmazturk, F., 2005, 3D-reconstruction of small historical objects to exhibit in virtual museum by means of digital photogrammetry, CIPA 2005 XX. International Symposium, International Cooperation to Save the World`s Cultural Heritage, 26 Sep.-01 Oct. 2005, Torino, Italy.

Remondino, F., 2011a, Heritage Recording and 3D Modeling with Photogrammetry and 3D Scanning. Remote Sens., 3, 1104-1138.

Remondino F., Barazzetti L., Nex F., Scaioni M., Sarazzi D., 2011b, UAV Photogrammetry for mapping and 3D modeling current status and future perspectives, ISPRS ICWG I/V UAV-g conference, Zurich, Switzerland.

Scherer M., 2002, About the synthesis of different methods in surveying, XVIII International Symposium of CIPA, Potsdam, Germany.

Suveg, I., Vosselman, G., 2000, “3D Reconstruction of Buildings Models”, IAPRS, Vol. XXXIII, Amsterdam.

Yakar, M., Y1lmaz H.M., 2008, Kültürel Miraslardan Tarihi Horozluhan'ın Fotogrametrik Rolove Calısması ve 3 Boyutlu Modellenmesi, S.U. Muh.- Mim. Fak. Dergisi c.23, s.2, (in Turkish)

Yakar, M., Yıldız F., Özkütük, A., Neşeli, O., Kurhan, E., Durdu, O., 2011, Sultanhanı Kervansarayı Fotogrametrik Rölöve Alımı ve 3 Boyutlu Modelleme Çalışması, Tmmob Harita Kadastro Mühendisleri Odası, 13. Türkiye Harita Bilimsel ve Teknik Kurultayı, (in Turkish)

W. Böhler, G. Heinz, 1999, Documentation, surveying, photogrammetry, XVII CIPA Symposium. Recife, Olinda. 